\title{
STRATEGI PENGEMBANGAN USAHA KECIL DALAM MENINGKATKAN PENDAPATAN PEDAGANG KELAPA MUDA (Cocos Nucifera $L$.) (Studi Kasus: Kecamatan Medan Kota, Kelurahan Teladan Barat)
}

\section{SMALL BUSINESS DEVELOPMENT STRATEGY TO INCREASE INCOME OF YOUNG COCONUT TRADERS (Cocos Nucifera L.) (Case Study: Medan Kota District, West Teladan Ward)}

\author{
Nia Aldina Lubis ${ }^{1}$, Mitra Musika Lubis ${ }^{2}$, Gustami Harahap 3 \\ Universitas Medan Area \\ Diterima: Oktober 2021 Disetujui: Oktober 2021 Dipublish: Oktober 2021
}

*Corresponding Email: Nialubis@gmail.com

\begin{abstract}
ABSTRAK
Tujuan Penelitian ini adalah untuk mengetahui pendapatan yang diperoleh pada usaha pedagang kecil kelapa muda di Kecamatan Medan Kota Kelurahan Teladan Barat, mengetahui strategi pengembangan usaha pedagang kecil kelapa muda di Kecamatan Medan Kota Kelurahan Teladan Barat. Penelitian ini dilaksanakan pada bulan Oktober-November 2019. Pada penelitian ini sampel yang diambil berdasarkan kriteria yaitu hanya pengusaha yang memiliki usaha es kelapa muda yang berbahan kelapa muda dari populasi yang berjumlah 24 pengusaha hanya 17 pengusaha. Metode penelitian ini bersifat deskriptif dengan sumber data primer yang diperoleh dari penyebaran kuesioner kepada responden. Hasil penelitian ini dari hasil perhitungan peneliti pada usaha es kelapa muda dengan nilai R/C ratio sebesar 1,35 lebih dari satu. Pendapatan yang didapat sebesar Rp 103.000,- dari total rata-rata penerimaan $\mathrm{Rp} 390.000$,- dibagi biaya rata-rata proses penjulan sebesar Rp 287.000,-. Berdasarkan hasil penelitian strategi pengembangan usaha merupakan pilihan strategi yang dilakukan pengusaha di Kecamatan Medan Kota, Kelurahan Teladan Barat untuk merebut peluang pasar. Pengusaha dapat memperoleh keunggulan bersaing yang lebih tinggi dibandingkan dengan pesaingnya jika dia dapat memberikan harga jual yang lebih murah dari harga yang diberikan oleh pesaingnya dengan nilai atau kualitas produk yang sama.
\end{abstract}

Kata Kunci: Biaya; Strategi Pengembangan; Pendapatan; Kelapa Muda

\begin{abstract}
This study aims to determine the Small Business Development Strategy in Increasing the Income of Young Coconut Traders (Cocos Nucifera L) (Case Study: Medan Kota District, Teladan Barat Ward). The objectives of this study were to determine the income earned from small coconut traders in Medan City, Teladan Barat Ward to determine the strategy for developing young coconut small traders in Medan City, Teladan Barat Ward. This research was conducted in October-November 2019. In this study the samples were taken based on the criteria, entrepreneurs who had young coconut ice-based businesses from a population of 24 entrepreneurs is 17 entrepreneurs. This research method was descriptive with primary data sources obtained from distributing questionnaires to respondents. The results of this study from the results of the researcher's calculations on the young coconut ice business with an $R / C$ ratio of 1.35 more than one. The income earned was $R p$ 103.000,- from the average total income of $R p$ 390,000, - divided by the average cost of the sales process of $R p$ 287,000. Based on the results of research on business development strategies, it was a strategic choice made by entrepreneurs in Medan Kota District, Teladan Barat Ward to seize market opportunities. Entrepreneurs can gain a higher competitive advantage than their competitors if they can provide a selling price that is cheaper than the price given by its competitors with the same value or product quality.
\end{abstract}

Keywords: Cost; Development Strategy; Income; Young Coconut 


\section{PENDAHULUAN}

Buah kelapa merupakan bagian paling penting dari tanaman kelapa karena mempunyai nilai ekonomis dan gizi yang tinggi. Buah kelapa tua terdiri dari empat komponen utama yaitu 35 persen sabut, 12 persen tempurung, 28 persen daging buah, dan 25 persen air kelapa. Daging buah kelapa selain nikmat disantap langsung (terutama kelapa muda), dapat diproses lebih lanjut. Hal ini dikarenakan pada umumnya produk pertanian memiliki sifat yang mudah rusak, maka produk pertanian harus segera dipasarkan dalam bentuk segar atau dapat diolah menjadi bahan pangan tahan simpan (Shantybio, 2006).

Buah kelapa muda merupakan salah satu produk tanaman tropis yang unik karena disamping komponen daging buahnya dapat langsung dikonsumsi, juga komponen air buahnya dapat langsung diminum tanpa melalui pengolahan. Keunikan ini ditunjang oleh sifat fisik dan komposisi daging dan air kelapa, sehingga produk ini sangat digemari konsumen baik anak-anak maupun orang dewasa (Rindengan Barlina, 2007).

Air kelapa masih dapat dimanfaatkan secara optimal karena mengandung beberapa kelebihan diantaranya adalah kandungan zat gizinya yang tinggi meliputi protein, vitamin, mineral serta gula yang baik bagi tubuh. Kandungan gula pada air kelapa berkisar antara 1,7-2,6\%, terdiri dari glukosa, sukrosa, dan fruktosa. Kelebihan lain yang dimiliki air kelapa adalah dapat digunakan sebagai anti racun yaitu tanin, enzim pengurai racun dan kaya akan elektrolit sehingga cocok untuk dibuat minuman 2 isotonik sebagai pengganti cairan tubuh yang keluar dan pengganti elektrolit saat dehidrasi untuk kasus diare (Irawan, 2007).

Karateristik usaha sektor informal khususnya pedagang kelapa muda kaki lima di Kecamatan Medan Kota, Kelurahan Teladan Barat pada umumnya untuk meningkatkan pendapatan hasil usahanya dan menciptakan strategi - strategi di dalam mengembangkan usahanya sehingga dapat bersaing antara sesama pedagang kaki lima dalam memperoleh hasil yang memuaskan. Berdasarkan uraian di atas maka penulis tertarik untuk berusaha mengkaji bagaimana strategi pengembangan usaha sektor informal dalam meningkatan pendapatan pedagang kelapa muda di Kecamatan Medan Kota Kelurahan Teladan Barat. Karena penulis melihat bisnis es kelapa muda tampaknya masih menjadi pilihan bagi sejumlah orang untuk meraup keuntungan karena, omset dari bisnis ini biasa mencapai jutaan rupiah walaupun terkadang ada penertiban pedagang kaki lima yang dimana Para Pedagang Kaki Lima (PKL) yang umumnya tidak memiliki keahlian khusus mengharuskan mereka bertahan dalam suatu kondisi yang memprihatinkan dengan begitu banyak kendala yang harus dihadapi seperti kurangnya modal, tempat berjualan yang tidak menentu, adanya PERDA yang melarang keberadaan mereka. Berdasarkan latar belakang di atas peneliti tertarik untuk meneliti dan menyusun skripsi dengan judul "Strategi Pengembangan Usaha kecil dalam Meningkatkan Pendapatan Kelapa Muda Kecamatan Medan Kota Kelurahan Teladan Barat”. 


\section{METODE PENELITIAN}

Penelitian ini dilakukan terhadap usaha penjual kelapa muda kaki lima yang terletak di Kecamatan Medan Kota, Kelurahan Teladan Barat. Pemilihan lokasi penelitian ini dilakukan secara sengaja (purposive) dengan pertimbangan di daerah tersebut merupakan salah satu tempat usaha penjual kelapa muda kaki lima. Waktu penelitian ini dilakukan dari bulan Oktober-November 2019.

Metode yang digunakan dalam penentuan sampel adalah metode sensus. Menurut Supranto (2003), sensus adalah kegiatan pencatatan yang menyeluruh terhadap elemen-elemen yang menjadi objek penyelidikan. Ini dilakukan terhadap populasi dengan jumlah sedikit. Sugiyono (2001: 61) menyatakan bahwa sampling purposive adalah penentuan sampel dengan pertimbangan tertentu. Menurut Margono (2004:128) pemilihan sekelompok subjek dalam purposive sampling didasarkan atas ciri ciri tertentu yang dipandang mempunyai sangkut paut yang erat dengan ciri- ciri populasi yang sudah diketahui sebelumnya dengan kata lain unit sampel yang dihubungi disesuaikan dengan kriteria-kriteria tertentu yang diterapkan berdasarkan tujuan penelitian. Pada penelitian ini sampel yang diambil berdasarkan kriteria yaitu hanya pengusaha yang memiliki usaha es kelapa muda yang berbahan kelapa muda dari populasi yang berjumlah 24 pengusaha hanya 17 pengusaha yang sesuai dengan kriteria pengambilan sampel yaitu:

1. Usaha utama adalah penjual es kelapa muda

2. Tempat usaha tetap di lokasi meskipun ada penertiban

3. Usaha yang dimiliki rata-rata di atas 5 tahun

4. Tetap berdagang meskipun di hari libur

\section{Teknik Analisis Data}

Metode analisis deskriptif yang digunakan dalam penelitian ini adalah dengan mengumpulkan, mengolah, mengklasifikasikan, dan menginterprestasikan data penelitian sehingga diperoleh gambaran yang jelas mengenai objek yang diteliti dan dengan mengetahui tahapan proses produksi kelapa muda penelitian yang bersifat deskriptif dengan sumber data primer yang diperoleh dari penyebaran kuesioner kepada responden.

\section{Menghitung Pendapatan Pedagang Kelapa Muda}

Pendapatan usaha kecil dapat dihitung dengan menggunakan pendekatan arus pengeluaran dan arus penerimaan. Arus penerimaan terdiri dari penerimaan dari produk yang dijual dan penerimaan dari produk yang dikonsumsi sendiri, namun tetap diperhitungkan. Arus pengeluaran terdiri dari pengeluaran tunai dan pengeluaran yang diperhitungkan.

a. Struktur Penerimaan Usaha

Penerimaan adalah perkalian antara produksi yang diperoleh dengan harga jual. Pernyataan ini dapat dituliskan sebagai berikut:

$$
\text { TR }=\text { Y. Py }
$$

Dimana:

$\mathrm{TR}=$ Total penerimaan $(\mathrm{Rp})$

$\mathrm{Y} \quad=$ Volume Penjualan (Rp) 
Py = Harga jual (Harga Output) (Rp)

a. Struktur Biaya Usaha

Biaya biasanya diklasifikasikan menjadi dua, yaitu Biaya Tetap (fixed cost) dan Biaya Tidak Tetap. Biaya Tetap (fixed cost) yaitu biaya yang penggunaannya tidak habis dalam satu masa produksi. Besarnya biaya tetap tidak tergantung pada jumlah output yang diproduksi dan tetap harus dikeluarkan walaupun tidak ada produksi. Komponen biaya tetap antara lain seperti sewa tanah, pajak, peralatan, dan iuran irigasi. Cara menghitung biaya tetap adalah:

$$
\mathrm{FC}=\mathrm{Xi} . \text { Pxi }
$$

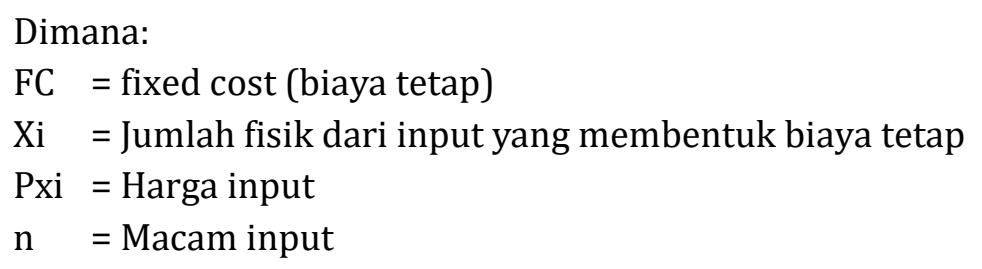

Biaya Tidak Tetap (variable cost) yaitu biaya yang besar kecilnya dipengaruhi oleh produksi yang diperoleh. Contohnya biaya untuk sarana produksi. Total biaya (TC) merupakan penjumlahan dari biaya tetap (FC) dan biaya tidak tetap (VC), yang dapat dirumuskan sebagai berikut:

Dimana:

$$
\mathrm{TC}=\mathrm{FC}+\mathrm{VC}
$$

$\mathrm{TC}=$ Total biaya

$\mathrm{FC}=$ Biaya tetap

$\mathrm{VC}=$ Biaya variabel

b. Pendapatan Usaha

Pendapatan adalah selisih antara penerimaan dan semua biaya. Jadi:

$$
\mathrm{Pd}=\mathrm{TR}-\mathrm{TC}
$$

Dimana:

$$
\begin{aligned}
& \mathrm{Pd}=\text { Pendapatan usaha }(\mathrm{Rp} / \mathrm{buah}) \\
& \mathrm{TR}=\text { Total penerimaan }(\mathrm{Rp} / \mathrm{buah}) \\
& \mathrm{TC}=\text { Total biaya }(\mathrm{Rp} / \mathrm{buah})
\end{aligned}
$$

c. Kelayakan Usaha

$\mathrm{R} / \mathrm{C}$ ratio merupakan perbandingan antara pendapatan total dan biaya produksi yaitu dengan menggunakan rumus sebagai berikut:

$$
\mathrm{RC}=\mathrm{TR} / \mathrm{T} \mathrm{C}
$$

$\mathrm{R} / \mathrm{C}>1$ berarti usaha Es kelapa muda layak diusahakan

$\mathrm{R} / \mathrm{C}=1$ berarti usaha es kelapa muda tidak rugi dan tidak untung

$\mathrm{R} / \mathrm{C}<1$ berarti usaha es kelapa muda tidak layak diusahakan

\section{Strategi Pengembangan}

Analisis strategi pengembangan mengikuti langkah-langkah di bawah ini untuk memiliki strategi perencanaan dan pengembangan bisnis kecil: pengorganisasian, kreativitas, pencatatan, kenali pesaing, konsisten/fokus, pelayanan. 


\section{HASIL PENELITIAN DAN PEMBAHASAN}

\section{Biaya Produksi}

Biaya produksi yang dikeluarkan dalam kegitan proses produksi dapat dibagi ke dalam dua bagian antara lain:

1. Biaya Implisit (biaya tetap) yaitu pengeluaran yang digunakan untuk memperoleh faktor-faktor produksi yang diperlukan usaha dalam kegiatan proses produksinya. Biaya-biaya tersebut antara lain: biaya tenaga kerja, pembelian bahan mentah, dan peralatan dan sebagainya.

2. Biaya Eksplisit (biaya variabel) merupakan biaya yang dipengaruhi oleh besar kecilnya volume produksi. Biaya yang digunakan dalam proses penjualan es kelapa muda.

\section{Penerimaan dan Pendapatan Usaha}

Pendapatan (keuntungan) merupakan selisih antara penerimaan dengan semua biaya. Rumusnya, Pd $=\mathrm{TR}-\mathrm{TC}$ dimana $\mathrm{Pd}$ adalah pendapatan, TR adalah total penerimaan dan TC adalah total biaya. Selanjutnya dikatakan, bahwa penerimaan diperoleh dari produksi fisik dikalikan dengan harga produksi. Total pendapatan bersih diperoleh dari total penerimaan dikurangi dengan total biaya dalam suatu produksi.

\section{Penerimaan}

Tabel 4. Penerimaan Rata-Rata Per Hari Proses Penjualan Es Kelapa

Muda Kecamatan Medan Kota, Kelurahan Teladan Barat 2019

\begin{tabular}{l|c|c} 
No & Uraian & Nilai \\
\hline $\mathbf{1}$ & Jumlah Penjualan (buah) & 26 \\
\hline $\mathbf{2}$ & Harga Jual (buah) & $15.000 /$ buah \\
\hline \multicolumn{2}{c}{ Penerimaan (Rp/buah) } & $\mathbf{R p ~ 3 9 0 . 0 0 0 , -}$
\end{tabular}

Sumber: data primer diolah, 2019

Dari Tabel 4 di atas maka dapat diketahui total penerimaan dari hasil perkalian antara jumlah rata-rata penjualan bahan baku sebesar 26 buah dan dengan rata-rata harga jual sebesar Rp 15.000/buah,- yaitu total penerimaan sebesar Rp 390.000,-.

\section{Pendapatan}

Dapat diketahui bahwa total penerimaan yang diterima dalam proses penjualan perharinya adalah sebesar Rp 390.000,- per 26 buah es kelapa muda dan dari Tabel 5 diketahui bahwa total biaya sebesar Rp 287.000,- per 26 buah es kelapa muda. Karena penerimaan lebih besar dari total biaya, maka usaha tersebut memiliki keuntungan. Besar rata-rata pendapatan diperoleh dari penjualan es kelapa muda per harinya adalah sebesar Rp 103.000,- per 26 buah es kelapa muda. 


\section{Kelayakan $\mathrm{R} / \mathrm{C}$ ratio}

Tabel 6. Tabel Tingkat Kelayakan Usaha per Hari Proses Produksi pada Usaha Es Kelapa Muda di Kecamatan Medan Kota Kelurahan Teladan Barat Tahun 2019

\begin{tabular}{l|c|c} 
No & Uraian & Nilai \\
\hline $\mathbf{1}$ & Total Penerimaan (Rp) & Rp 390.000 \\
\hline $\mathbf{2}$ & Total Biaya & Rp 287.000 \\
\hline & R/C ratio & $\mathbf{1 . 3 5}$
\end{tabular}

Sumber: Data primer diolah Tahun, 2019

Dari Tabel 6. di atas dapat diketahui bahwa nilai $\mathrm{R} / \mathrm{C}$ ratio pada usaha es kelapa muda di Kecamatan Medan Kota Kelurahan Teladan Barat adalah sebesar 1,35 yang artinya setiap biaya produksi dikeluarkan sebesar $>$ 1.- maka pengusaha es kelapa muda di Kecamatan Medan Kota Kelurahan Teladan Barat akan mendapatkan penerimaan sebesar Rp 1.35. Hal ini menunjukkan bahwa usaha tersebut layak untuk dikembangkan karena nilai $\mathrm{R} / \mathrm{C}$ ratio lebih dari 1.

\section{Strategi Pengembangan Dalam Perluasan Skala Usaha}

Tabel 7. Membuat Anggaran yang Bertujuan Seberapa Besar Pemasukan dan Pengeluaran Pengusaha

\begin{tabular}{c|l|c|r} 
No. & \multicolumn{1}{|c|}{ Alternatif Jawaban } & $\begin{array}{c}\text { Sampel } \\
\text { (orang) }\end{array}$ & \multicolumn{2}{|c}{$\begin{array}{c}\text { Persentase } \\
\text { (\%) }\end{array}$} \\
\hline 1. & Sangat Setuju & 8 & 47,1 \\
\hline 2. & Setuju & 4 & 23,5 \\
\hline 3. & Cukup Setuju & 5 & 29,4 \\
\hline 4. & Tidak Setuju & - & - \\
\hline 5. & Sangat Tidak Setuju & - & $\mathbf{1 0 0}$
\end{tabular}

Tabel 7 menunjukkan bahwa 8 orang atau 47,1\% menyatakan jawaban sangat setuju, 4 orang atau 23,5\% menyatakan jawaban setuju, 5 orang atau 29,4\% menyatakan cukup setuju. Hal ini berarti sebagaian besar responden merasa yakin dengan membuat anggaran yang bertujuan seberapa besar pemasukan dan pengeluaran pengusaha.

\section{Strategi Pengembangan Usaha Dalam Perluasan Cakupan Usaha}

Berdasarkan Tabel 7 menunjukkan bahwa sebagian besar responden merasa yakin dengan membuat anggaran yang bertujuan seberapa besar pemasukan dan pengeluaran pengusaha. Agar tidak terjadi kesalahan saat melakukan pengeluaran dan pemasukkan. Hal ini pun bisa menjadi keliru karena jika tidak membuat anggaran pengeluaran dan pemasukkan penjualannya akan merugi dan mengalami penurunan pendapatan. 


\section{KESIMPULAN DAN SARAN}

\section{Kesimpulan}

Berdasarkan hasil penelitian yang dilakukan usaha penjual Es Kelapa Muda di Kecamatan Medan Kota, Kelurahan Teladan Barat diperoleh kesimpulan sebagai berikut:

1. Dari hasil perhitungan peneliti pada usaha es kelapa muda dengan nilai $\mathrm{R} / \mathrm{C}$ ratio sebesar 1,35 lebih dari satu. Pendapatan yang didapat sebesar $\mathrm{Rp}$ 103.000,- dari total rata-rata penerimaan $\mathrm{Rp} 390.000$,- dibagi biaya rata-rata proses penjulan sebesar Rp 287.000,--.

2. Berdasarkan hasil penelitian strategi pengembangan usaha merupakan pilihan strategi yang dilakukan pengusaha di Kecamatan Medan Kota, Kelurahan Teladan Barat untuk merebut peluang pasar. Pengusaha dapat memperoleh keunggulan bersaing yang lebih tinggi dibandingkan dengan pesaingnya jika dia dapat memberikan harga jual yang lebih murah dari harga yang diberikan oleh pesaingnya dengan nilai atau kualitas produk yang sama.

\section{Saran}

Bedasarkan hasil dan kesimpulan penelitian maka saya saran yang dapat saya sampaikan sebagai berikut:

1. Kepada pengusaha agar meminta kejelasan kepada pemerintah mengenai ijin lokasi tempat yang sah secara tertulis untuk pembenahan lokasi penjualan.

2. Kepada pengusaha agar lebih mengikuti perkembangan zaman agar dapat bersaing dengan pesaing usaha minuman musiman.

\section{DAFTAR PUSTAKA}

Anoraga, Pandji dan Ninik Widiyanti. (2007). Dinamika Koperasi. Cetakan kelima. Jakarta: PT Rineka Cipta.

Amin, Sarmidi.( 2009). Cocopreneurship: Aneka Peluang Bisnis dari Kelapa.Yogyakarta: Penerbit Lily Publisher. 166 hal.

Abdul Masse, Afandi. (2017). Analisis Pendapatan Dan Kelayakan Usahatani Kelapa Dalam Di Desa Kasoloang Kecamatan Bambaira Kabupaten Mamuju Utara Provinsi Sulawesi Barar Ata-Rata Pendapatan Usahatani Kelapa. Palu: Jurnal, Universitas Tadulako.

Barlina, Rindengan. (2007). Pengaruh perbandingan air kelapa dan penambahan daging kelapa muda serta lama penyimpanan Terhadap Serbuk minuman Kelapa. Jurnal Littri Vol 13 (12): 73-80.

Irawan, M.A. (2007). Glukosa dan Metabolisme Energi. Sport Science Brief.1(6):12-5. Iwantono, S. (2002). Kiat Sukses Berwirausaha. Jakarta: Gramedia.

Ismail Solihin. (2006). Pengantar Bisnis, Jakarta: Kencana, hal, 123-125.

Kudo. (2017). Pengembangan Bisnis. PT kudo Teknnologi Indonesia.

Lecup dan Nicholson. (2006). Tingkat Ketergantungan Masyarakat Desa Labuaja Terhadap Zona Tradisional Taman Nasional Bantimurung Bulusaraung.

Manaili., Sajise. ( 1996). Pembangunan Agroindustri Berkelanjutan. Yogyakarta: Kanisius. Margono. (2004). Metodologi Penelitian Pendidikan, Jakarta: Rineka Cipta.

Novia, Riyanzie. (2012). Analisis Strategi Pengembangan Usaha Industri Kecil Souvenir di Kelurahan Penggilingan Kecamatan Cakung Kota Administrasi. Jakarta Timur. 
Nia Aldina Lubis ${ }^{1}$, Mitra Musika Lubis ${ }^{2}$, Gustami Harahap ${ }^{3}$, STRATEGI PENGEMBANGAN USAHA KECIL DALAM MENINGKATKAN PENDAPATAN PEDAGANG KELAPA MUDA (Cocos Nucifera L.) (Studi Kasus: Kecamatan Medan Kota, Kelurahan Teladan Barat)

Rachbini, D.J. ( 2011). Dampak Impor: Proteksi Negara terhadap Petani Lemah (dalam Kompas, 19 Oktober 2011)

Sumarwan, Ujang, dkk. ( 2009). Strategi Pemasaran Untuk Pertumbuhan Dalam Penciptaan Nilai Bagi Saham. Inti Prima Promosindo jakarta.

Shantybio. (2006). Nata De Coco Yang Kaya Serat Biology Mikrobiologi. http:// Transdigit.com.

Suryana. (2001). Kewirausahaan. Jakarta: Penerbit Salemba Empat.

Soekartawi. (1995). Analisis Usahatani. Jakarta: Universitas Indonesia Press.

Soekartawi. (2000). Pengantar Agroindustri. Jakarta: PT Raja Grafindo Persada.

Sugiyono. (2007). Metode Penelitian Bisnis. Bandung: Alfabeta

Supranto, J. ( 2003). Metode Riset Aplikasi Dalam Pemasaran. Edisi Revisi Ketujuh. Yogyakarta: Rineka Cipta.

Wicaksono. (2013) Analisis Usaha dan Strategi Pengembangan Agroindustri Keripik Pisang Agung Studi Kasus Pada Kabupaten Lumajang, Semarang: Universitas Negeri Semarang. 